\title{
EVALUASI TUGAS CAMAT DALAM MEMBINA PENYELENGGARAAN PEMERINTAHAN DESA DI KECAMATAN ROKAN IV KOTO KABUPATEN ROKAN HULU
}

\author{
Syafhendry ${ }^{1}$ \\ Delpi Susanti ${ }^{2}$ \\ Program Pasca Sarjana Ilmu Pemerintahan \\ Universitas Islam Riau \\ Svafhendrv.ip@soc.uir.ac.id
}

\begin{abstract}
Abstrak
Penelitian ini bertujuan untuk mengetahui dan menjelaskan hasil pelaksanaan kewenangan Camat dalam Membina Penyelenggaraan Pemerintah Desa di Kecamatan Rokan IV Koto Kabupaten Rokan Hulu dan mengetahui faktor-faktor Penghambat Tugas Camat dalam Membina Penyelenggaraan Pemerintah Desa, serta untuk mengetahui pola pembinaan yang cocok untuk penyelenggaraan pemerintahan desa terkhusus di Kecamatan Rokan IV Koto penelitian ini berbentuk penelitian lapangan dengan cara survey dengan olahan skala likert, sedangkan ditinjau dari sifatnya penelitian ini bersifat analisa deskriptif yaitu menerangkan dan mengembangkan berbagai temuan penelitian dilapangan serta menganalisa data sehinggaa di peroleh suatu jawaban atas permasalahan yang dirumuskan, mengingat jumlah populasi sebagian besar dan sebagian ada yang kecil, maka peneliti melakukan pengambilan sampel. Untuk Kepala Desa langsung dibatasi pada 3 Desa dengan 3 Kepala Desa, Sekretaris Desa dengan 3 sekdes, Kaur Pemerintahan Desa 3, Kepala Dusun 3, dan BPD 19 menggunakan teknik mengunakan teknik sampling jenuh istilah lain teknik sensus. Untuk menganalisa data, dalam hal ini data yang telah terkumpul dikelompokkan menurut jenis data masing-masing kemudian disajikan dalam bentuk table skala likert. dari hasil pembahasan yang telah dilakukan maka dapat ditarik kesimpulan antara lain adalah : Evaluasi Tugas Camat dalam Membina Penyelenggaraan Pemerintahan Desa di Kecamatan Rokan IV Koto Kabupaten Rokan Hulu dengan 6 indikator penilaian yaitu : Efisiensi, Efektivitas, Responsivitas, Supervisi, Konsultasi Pelaksanaan Urusan Pemerintah, maka dapat dikategorikan Cukup Baik. Berdasarkan item pengamatan observasi hambatan yang dihadapi dalam pelaksanaan penyelenggaraan pemerintahan desa adalah anggaran dana untuk pelaksanaan kegiatan tersebut sehingga pada unsur pembina adalah merupakan unsur utama yang harus diperbaiki sebelum melakukan pembinaan terhadap yang dibina terkhusus di Kecamatan Rokan IV Koto Kabupaten Rokan Hulu.
\end{abstract}

Kata kunci : Evaluasi, Tugas Camat, Pembinaan

JURNAL KAJIAN PEMERINTAHAN VOLUME IV NOMOR 1 MARET 2018 


\begin{abstract}
study aims to determine and explain the results of the implementation of the authority of the Camat in fostering the Implementation of Village Government in Rokan IV Koto Sub-District Rokan Hulu and to know the factors inhibiting the tasks of the sub-district Head in fostering the Village Government, and to know the appropriatepattern of coaching for the implementation of the village government in Rokan IV Koto Subdistrict, this research is in the form of field research by way of survey with Likertscale processing, while viewed from the nature of this research is descriptive analysis that explains and develops various research findings in the field and analyze the data so that obtained an answer to the problems formulated, the population is mostly and some are small, so the researchers do the sampling. For the Village Headis directly limited to 3 Villages with 3 Village Heads, Village Secretaries with 3 Sekdes, Village Governors 3, Dusun Head 3, and BPD 19 using techniques using saturated sampling techniques other term census techniques. To analyze the data, in this case the data that have been collected are grouped according to each data type then presented in Likert scale table. Furthermore, the data that has been presented in the form of the table is analyzed descriptively, ie analysis in the form of descriptions and explanations of the table presented, from the results of the discussion that has been done it can be drawn conclusions, among others are: Evaluation of District Camat in Fostering the Implementation of Village Government in Rokan IV Koto Sub-district Rokan Hulu District with 6 indicators of assessment are: Efficiency, Effectiveness, Responsiveness, Supervision, Consultation of Government Affairs Implementation, it can be categorized as Good Enough. Based on observation items obstacles observation faced in the implementation of village administration is the budget for the implementation of these activities so that the element of the builder is amajor element that must be improved prior to coaching on the specially developed in Rokan IV Koto District Rokan Hulu District.
\end{abstract}

Keywords: Evaluation, Tasks of Sub-district, Coaching

\section{Latar Belakang}

$\begin{array}{ccc}\text { Sebagaimana kita } & \text { ketahui } \\ \text { bahwa dalam } & \text { praktek }\end{array}$ penyelenggaraan pemerintahan daerah sesuai dengan UndangUndang Nomor 23 Tahun 2014 tentang Pemerintahan Daerah. Pemberian otonomi yang seluasluasnya kepada Daerah menurut undang-undang tersebut diarahkan untuk mempercepat terwujudnya kesejahteraan masyarakat melalui peningkatan pelayanan, pemberdayaan, dan peran serta, prakarsa dan pemberdayaan masyarakat yang bertujuan untuk peningkatan kesejahteraan masyarakat. 
Keberadaan Pemerintahan Daerah yaitu pelaksanaan fungsifungsi Pemerintahan Daerah yang dilakukan oleh Lembaga Pemerintahan Daerah, yaitu Pemerintah Daerah dan Dewan Perwakilan Rakyat Daerah (DPRD). Pengaturan tentang Pemerintahan Daerah pada saat ini didasarkan pada Undang-Undang Nomor 23 Tahun 2014 Tetang Pemerintahan Daerah. ${ }^{1}$

Pemerintahan Daerah adalah penyelenggaraan urusan pemerintahan oleh Pemerintahan Daerah dan Dewan Perwakilan Rakyat Daerah menurut azas otonomi dan tugas pembantuan dengan prinsip otonomi seluasluasnya dalam sistem dan prinsip Negara Kesatuan Republik Indonesia sebagaimana dimaksud dalam UUD 1945. ${ }^{2}$

Negara Kesatuan Republik Indonesia dibagi atas Daerah provinsi dan Daerah provinsi itu dibagi atas Daerah kabupaten dan kota. Selanjutnya pada Daerah kabupaten/kota dibagi atas Kecamatan dan Kecamatan dibagi atas kelurahan dan/atau Desa. ${ }^{3}$ Urusan pemerintahan dikelompokkan kedalam tiga urusan, yaitu urusan pemerintahan obsolut, urusan pemerintahan

${ }^{1}$ Ateng Syafrudin, 2006. Mengarungi Dua

Samudra, Sayagatama, Jakarta, hlm.325

${ }^{2}$ Pasal 1 (2) Undang-Undang Nomor 23

Tahun 2014 tentang Pemerintahan Daerah

${ }^{3}$ Ibid. Pasal 2 ayat (1-2) konkuren dan urusan pemerintahan umum. ${ }^{4}$

Daerah Kabupaten/Kota membentuk Kecamatan dalam rangka meningkatkan koordinasi penyelenggaraan pemerintahan, pelayanan public, dan pemberdayaan masyarakat Desa/Kelurahan. ${ }^{5}$

Kedudukan Camat juga dijelaskan sebelumnya bahwa Kecamatan adalah perangkat daerah Kabupaten/kota sebagai berikut : Perangkat Daerah kabupaten/kota terdiri atas:

a. sekretariat daerah;

b. sekretariat DPRD;

c. inspektorat;

d. dinas;

e. badan; dan

f. Kecamatan. ${ }^{6}$

Jadi Kecamatan dibentuk dalam rangka meningkatkan koordinasi penyelenggaraan pemrintahan artinya dengan adanya Kecamatan, Camat sebagai pimpinan tertinggi di Kecamatan harus dapat mengkoorkinasikan semua urusan pemerintahan di Kecamatan, kemudian juga Camat harus memberikan pelayanan publik di Kecamatan dan juga pemberdayaan masyarakat Desa/Kelurahan.

Selanjutnya ditegaskan bahwa Kecamatan dipimpin oleh seorang Kepala Kecamatan yang disebut Camat yang berada dibawah dan bertanggung jawab
${ }^{4}$ Ibid. Pasal 9
${ }^{5}$ Loc. Cit, Pasal 221 ayat (1), Hlm.3
${ }^{6}$ Loc. Cit, pasal 209 ayat (2) huruf f, Hlm.3

JURNAL KAJIAN PEMERINTAHAN VOLUME IV NOMOR 1 MARET 2018 
kepada Bupati/Wali Kota melalui sekretaris Daerah. $^{7}$

Pelimpahan sebagian kewenangan dari Bupati kepada Camat yang bersifat Delegatifuntuk melaksanaakan urusan Pemerintahan Daerah, tugas dan kewenagnan Camat yang salah satunya yaitu Pembinaan Kemudian Camat juga memiliki Kewenangan atributif. Pada dasarnya wewenang adalah pengertian yang berasal dari hukum organisasi pemerintahan, yang dapat dijelaskan sebagai keseluruhan aturan-aturan yang berkenan dengan perolehan dan penggunaan wewenang pemerintahan oleh subjek hukum publik didalam hubungan hukum publik. ${ }^{8}$

Kemudian Pendelegasiannya Secara teoritis kewenangan yang bersumber dari peraturan perundang-undangan, ini diperoleh melalui tiga cara, yakni :
a. Atribusi,
b. Delegasi dan
c. Mandat
Camat Selain melaksanakan tugasnya sebagaimana yang diamatkan Undang-Undang No. 23

Tahun 2014 dan Peraturan Pemerintah No. 19 Tahun 2008, selanjutnya Undang-Undang Nomor 6 Tahun 2014 Tentang Desa yang dipertegas dengan Peraturan Pemerintah No. 43 Tahun 2014 mengisyaratkan bahwa Camat Wajib membina dan mengawasi

${ }^{7}$ Loc. Cit, pasal 224 ayat (1), Hlm.3

${ }^{8}$ H. D. Stout dalam Ridwan HR, 2006. Hukum Administrasi Negara, PT. Raja Grafindo Persada, Jakarta, hlm.101 penyelenggaraan pemerintahandesa. pembinaan dan pengawasantersebut meliputi :

a. Fasilitas penyususan Peraturan Desa dan Peraturan KepalaDesa;

b. Fasilitas administrasi Tata Pemeritnahan Desa

c. Fasilitas pengelolaan Keuangan Desa dan Pendayagunaan aset Desa;

d. Fasilitas penerapan dan penegakan peraturan perundangundangan;

e. Fasilitas pelaksanaan tugas Kepala Desa dan Perangkat Desa;

f. Fasilitas pelaksanaan pemilihan kepala Desa

g. Fasilitas pelaksanaan tugas dan Fungsi Badan Permusyawaratan Desa

h. Rekomendasi Pengangkatan dan Pemberhentian Perangkat Desa;

i. Fasilitas sinkronisasi perencanaan pembangunan daerah pembangunan desa;

j. Fasilitas penetapan lokasi pembangunan kawasan pedesaan;

k. Fasilitas penyelenggaraan ketentraman dan ketertiban umum;

1. Fasilitas pelaksanaan tugas, fungsi dan kewajiban lembaga masyarakat

m. Fasilitas penyusun perencanaan pembangunan partisipatif;

n. Fasilitas kerja sama antar Desa dan kerja sama Desa dengan Pihak ketiga;

o. Fasilitasi penataan, pemanfaatan dan pendayagunaan ruang Desa 
serta penetapan dan penegasan batas Desa;

p. Fasilitasi penyusunan program dan pelaksanaan pemberdayaan masyarakat Desa;

q. Koordinasi pendampingan Desa di wilayah; dan

r. Koordinasi pelaksanaan pembangunan kawasan perdesaan diwilayah. ${ }^{9}$

Kabupaten Rokan Hulu adalah salah satu kabupaten di Provinsi Riau dengan Ibu Kotanya terletakdi Pasir Pengaraian. Secara administratif , kabupaten ini memiliki 16 Kecamatan, 7 Kelurahan dan 149 desa. Kabupaten Rokan Hulu dijuluki Negeri Seribu Suluk. Sementara itu, Kecamatan Rokan IV Koto adalah Kecamatan di Kabupaten Rokan Hulu dengan ibu kota Kecamatan berada di Rokan.

Salah satu Kecamatan yang diberikan tanggungjawab membina desa adalah Kecamatan Rokan IV Koto Kabupaten Rokan Hulu. Kecamatan Rokan IV Koto memiliki luas wilayah +- 1.130,45 $\mathrm{Km} 2$ yang membawahi 13 Desa dan 1 Kelurahan.

Sebagai tindak lanjut dari Peraturan Pemerintah No. 19 Tahun 2008 Tentang Kecamatan yang berkaitan dengan urusan otonomi daerah ini juga di perjelas dengan adanya Peraturan Bupati Rokan Hulu Nomor 39 Tahun 2011

${ }^{9}$ Pasal 154 ayat (2) Peraturan Pemerintah Nomor 43 Tahun 2014 Tentang Peraturan Pelaksanaan Undang-undang Nomor 6 Tahun 2014 Tentang Desa
Tentang Pelimpahan sebagian kewenagnan Bupati Rokan Hulu kepada Camat untuk melaksanakan urusan pemerintahan daerah Camat melaksanakan kewenangan pemerintahan yang dilimpahkan oleh Bupati/Walikota.

Pembinaan itu sendiri dimaksudkan agar penyelenggaraan pemerintahan desa berjalan dengan efektif, sehingga pelayanan terhadap masyarakat dapat berjalan semaksimal mungkin.

Selanjutnya penelitian ini di latarbelakangi juga oleh beberapa fenomena yang berkembang saat ini terutama pada level Kecamatan belum optimalnya Camat dalam melaksanakan tugasnya baik atributif maupun delegatif, yang salah satunya membina penyelenggaraan pemerintahandesa.

Belum ditemukan pola yang cocok digunakan Camat sebagai pembina dalam menyelenggarakan pembinaan terhadap pemerintahan desa sebagai objek yang dibina. Adapun persolaan penting yang akan dikaji dilihat dari 2 aspek yaitu pada aspek pembina yaitu Camat Sendiri yang menurut peneliti ada apa dengan pembinaan itu, dan yang kedua pada aspek yang dibina, ini persoalan dalam pengalaman penelitian terdahulu penulis melihat ada persoalan dari Camat sendiri yang belum tuntas melakukan pembinaan. Dimana pada pemerintahan desa sendiri dariaspek hasil pembinaan belum memberikan dampak perubahan yang berarti dalam 
penyelenggaraan pemerintahandesa yang baik.

Berdasarkan prasurvey yang dilakukan di Kecamatan Rokan IV Koto Kabupaten Rokan Hulu terlihat ada beberapa indikasi yang merupakan suatu Fenomena, yaitu diantaranya :

Data tahun 2017 didugabelum sepenuhnya terlihat Peranan Camat dalam Penyelenggaraan Pemerintahan Desa di Kecamatan Rokan IV Koto Kabupaten Rokan Hulu,yakni :

1. Penyelenggaraan dan pengawasan tertib administrasi pemerintah desa terindikasi belum sepenuhnya terlaksana, sehingga administrasi pemerintahan desa belum tertata dengan baik. Contohnya laporan administrasi kependuduka belum secara rutin dilaporkan (tidak tepat waktu), ADD ada desa yang belum membuat SPJ, data dasar keluarga (DDK) dan profil desa tidak dilaporkan, serta peraturan desa (perdes) dan peratuan Kepala Desa (Perkades) hanya sebagian desa yang melaporkan kekecamatan.

2. Belum optimalnya pelaksanaan memberikan fasilitasi, bimbinangan, pertemuan (diskusi), penyuluhan, pengarahan dan memberikan pelatihan terhadap kepala desa yang dilakukan oleh camat. Sebagai contoh rendahnya pengetahuan kepala desa dan perangkat desa mengenai administrasi desa. Sehingga laporan administrasi desa tidak dilaporkan secara rutin tiap bulannya seperti jenis laporan diatas. Hal ini menunjukan belum optimalnya pelaksanaan memberikan fasilitasi, bimbingan, pertemuan (diskusi), penyuluhan, pengarahan dan memberikan pelatihan terhadap kepala desa dan perangkat desa, sehingga rendahnya pengetahuan kepala desa dan perangkat desa dalam penyelenggaraan pemerintahan desa.

3. Belum optimalnya Camat melakukan evaluasi Pembinaan dan pengawasan setiap tahunnya dalam Penyelenggaraan administrasi pemerintahan desa, hal ini dibuktikan dengan prasurvey yaitu berkaitan masalah pajak ADD. Ini merupakan fenomena bahwa evaluasi dan pengawasan terhadap tertib administrasi pemerintahan desa diduga belum optimal dilaksanakan.

4. Terindikasi bahwa Camat dalam Pelaksanaan Fasilitas pelaksanaan tugas dan Fungsi Badan Permusyawaratan Desa juga belum mengadakan pelatihan dan penyuluhan terlihat dari Perangkat BPD yang belum tau akan tugas dan Fungsinya. Seperti belum tersalurnya aspirasi masyarakat terkait pembentukan peraturan Desa yang terinsikasi sifatnya hanya menyetujui, dimana kepala desa yang terkesan buru-buru dalam memberikan pelaporan kepada Camat sehingga BPD tidak membaca laporannya dan langsung menandatangani. Ini juga diindikasikan bahwa Camat belum mengetahui Pola Pembinaan yang tepat dalam meningkatkan kualitas pembinaan dalam penyelenggaraan 
pemerintahan desa ini juga sesuai dengan survey peneliti dimanapihak kecamatan sendiri tidak memiliki data pembinaan dan pelatihan yang dikatakan.

\section{dentifikasi Masalah}

Memperhatikan uraian diatas, masalah-masalah yang penulis dapat identifikasikan adalah sebagai berikut :

1. Belum jelasnya model atau Pola pembinaan yang dilakukanoleh Camat dalam Membina Penyelenggaraan Pemerintahan Desa.

2. Belum Optimalnya Pembinaan terkait Fasilitasi Penyusunan Peraturan Desa dan Peraturan Kepala Desa, fasilitasi administrasi tata pemerintahandesa, fasilitasi pelaksanaan tugas kepala desa dan perangkat desa dan fasilitasi pelaksanaan tugas dafungsi Badan Permusyawaratan desa.

3. Terbatasnya jumlah Sumber Daya Manusia yang Produktif, Kreatif dan Inovatif untuk mendukung administrasi pemerintahan.

\section{Rumusan Masalah}

a. Bagaimanakah Hasil Pembinaan Camat dalam Penyelenggaraan Pemerintah Desa di Kecamatan Rokan IV Koto Kabupaten Rokan Hulu?

b. Faktor-faktor apa saja yang menghambat Tugas Camatdalam

Membina

Penyelenggaraan Pemerintah
Desa di Kecamatan Rokan IV

Koto Kabupaten Rokan Hulu?

\section{Batasan Masalah}

Dari 18 (delapan belas)

Penyelenggaraan dan pengawasan desa yang dilakukan Camat pada Peraturan Pemerintah Nomor 43 Tahun 2014 Tentang Peraturan Pelaksanaan Undang-undang Nomor 6 Tahun 2014 Tentang Desa, maka penulis membatasi penelitian in dalam 3 (tiga) poin, yaitu :

1. Fasilitasi penyusunan Peraturan Desa dan Peraturan KepalaDesa, dengan sub indikator;

a. Memberikan bimbingan dan buku panduan

b. Melakukan pertemuan/diskusi (musyawarah)

c. Mengadakan pelatihan

2. Fasilitasi administrasi tata pemerintahan desa, dengan sub indikator;

a. Adanya bimbingan dari atasan

b. Adanya pemberian contoh yang baik kepada bawahan

c. Adanya pemberian motivasi

3. Fasilitasi pelaksanaan tugas Kepala Desa dan Perangkat Desa, dengan sub indikator;

a. Memberikan penyulluhan

b. Memberikan pengarahan

c. Adanya tim pengawasan

\section{Tujuan Penelitian}

Tujuan Penelitian ini adalah :

a. Untuk mengetahui dan menjelaskan hasil pelaksanaan kewenangan Camat dalam Membina Penyelenggaraan 
Pemerintah Desa di Kecamatan Rokan IV Koto Kabupaten Rokan Hulu

b. Untuk menngetahui faktor-faktor Penghambat Tugas Camat dalam Membina Penyelenggaraan Pemerintah Desa di Kecamatan Rokan IV Koto Kabupaten Rokan Hulu.

\section{Manfaat Penelitian} Manfaat Teoritis

a. Sebagai pengembangan ilmu pengetahuan dan untuk Menambah wawasan terutama dalam jurusan Ilmu Pemerintahan.

b. Sebagai bahan referensi dan informasi bagi pihak lain yang akan melakukan penelitian pada permasalahan yang sama.

c. Guna teoritis, yakni penelitian diharapkan dapat memacu perkembangan ilmu pemerintahan,minimal dapat memperkaya inventaris hasilhasil penelitian dibidang pemerintahan.

\section{Manfaat Praktis}

1. Sebagai bahan masukan dan bahan pertimbangan bagi Camat Rokan IV Koto

2. Guna praktis, yakni penelitian ini diharapkan menjadi bahan masukan bagi Camat Rokan IV Koto tentang Penyelenggaraan Pemerintah Desa di Kecamatan Rokan IV Koto

3. Guna akademis, yakni penelitian ini diharapakan menjadi bahan informasi dan data sekunder bagi kalangan akademis yang ingin meneliti hal yang sama.

\section{Kajian Pustaka}

Ilmu Pemerintahan adalah ilmu yang mempelajari bagaimana menyeimbangkan pelaksanaan kepengurusan (eksekutif), pengaturan (legislatif), kepemimpinan dan koordinasi pemerintahan (baik pusat dengan daerah, maupun rakyat dengan pemerintahannya) dalam berbagai peristiwa dan gejala pemerintahan, secara baik dan benar.

Pembinaan bisa berupa Proses, atau pernyataan tujuan.Pembinaan bisa menunjuk kepada "Perbaikan" atas sesuatu. Miftah Th, 2010. Ilmu Administrasi Publik Kontemporer. Kecana Prenada Media Group, Hlm.207

Pembinaan atas penyelenggaraan pemerintahan dilaksanakan oleh pemerintah yang meliputi :

1. Pemberian Bimbingan

2. Supervisi

3. Konsultasi Pelaksanaan urusan pemerintahan

Pedoman Pembinaan dan Pengawasan Penyelenggaraan Pemerintahan Daerah.

Evaluasi dapat disamakan dengan penaksiran,pemberian angka dan penilaian evaluasi berkenaan dengan produksi informasi mengenai nilai atau manfaat hasil kebijakan yaitu evaluasi memberi informasi yang valid dan dapat dipercaya mengenai kinerja kebijakan yaitu seberapa jauh kebutuhan,nilai,dan kesempatan telah dapat dicapai melalui tindakan 
publik. Konsep ini mengemukakan enam langkah dalam evaluasi kebijakan:

1. Efektivitas yaitu apakah hasil yang diinginkan telah tercapai.

2. Efesiensi yaitu seberapa banyak usaha diperlukan untuk mencapai hasil yang diinginkan

3. Responsivitas yaitu apakah hasil kebijakan memuaskan kebutuhan, prefensi atau nilai kelompok-kelompok tertentu.

\section{Metode Penelitian \\ Tipe Penelitian}

Untuk mendapatkan data dan keterangan yang mendukung dalam penelitian ini maka penulis menggunakan tipe penelitian deskriptif, penelitian deskriptif adalah penelitian yang menggambarkan keadaan yang sesungguhnya mengenai objek penelitian yang penulis telitidengan memprioritaskan alat bantu penelitian berupa kuisioner yang dilakukan untuk mengetahui nilai variabel. Adapun untuk jenis data dan analisis dalam penelitian ini adalah menggunakan data Kuantitatif.

\section{Lokasi Penelitian}

Lokasi penelitian dilaksanakan di Kecamatan Rokan IV Koto Kabupaten Rokan Hulu. Kecamatan ini dipilih sebagai lokasi penelitian adalah karena aparatur pemerintah desa di Kecamatan Rokan IV Koto masih memiliki pendidikan yang masih rendah, dan kurangnya mengikuti bimbingan teknis (Bimtek) serta pendidikan dalam latihan (Diklat) tentang pemerintahan desa, kondisi ini mengakibatkan kurang tertibnya dalam urusan penyelenggaraan pemerintah desa terutama pelaksanaan administrasi desa diwilayah Kecamatan Rokan IV Koto Kabupaten Rokan Hulu.

Adapun teknik penarikan sampel dalam penelitian ini adalah untuk Camat, Sekretaris Camat Penarikan Sampel mengunakan teknik sampling jenuh istilah lain teknik sensus, yaitu penetapansecara keseluruhan dari populasi Adapun untuk alasan pengambilan Populasi dan sampel pada penelitian ini dimana untuk Camat dan Sekcam karena mereka sebagai unsur pembina jadi Camat dan Sekcam dijadikan responden dalamkuisioner dan wawancara.

Selanjutnya untuk Kepala Desa langsung dibatasi pada 3 Desa dengan 3 Kepala Desa, Sekretaris Desa dengan 3 sekdes, Kaur Pemerintahan Desa 3, Kepala Dusun 3, dan BPD 19 menggunakan teknik mengunakan teknik sampling jenuh istilah lain teknik sensus. Untuk desanya penulis menentukan Desa Lubuk Bendaharan, Desa Alahan dan Desa Tibawan.

\section{Teknik Analisis Data}

Proses analisis data dimulai dengan menelaah seluruh data yang diperoleh dari proses pengumpulan data dilapangan dan data yang didapat dari berbagai sumber.

\section{Uji Validitas Data}


Pengujian Validitas digunakanuntuk mengukur sah/valid atau tidaknya butir kuisioner. Kuisioner dikatakan valid jika butir pertanyaan kuisioner mampu untuk mengungkapkan sesuatu yang akan diukur. Pengukuran tingkatvaliditas dalam penelitian ini menggunakan variabel/konstruk tertentu yang disebut variabel latern atau faktor, dimana variabel tersebut tidak diukur secara langsung, akan tetapi melalui indikator atau dimensi untuk diteliti, secara umum berupa butir pertanyaan/kuisioner yang terdapat alternatif jawaban yang tersedia dengan skala ordinal (skala likert), namun dalam penelitian ini menggunakan 3 (tiga) tingkat skala

\section{Deskripsi Lokasi Penelitian}

Kabupaten Rokan Hulu adalah salah satu Kabupaten di Provinsi Riau, Indonesia, yang dijuluki dengan Negeri Seribu Suluk.

Kecamatan Rokan IV Koto adalah salah satu kecamatan yang berada dikabupaten Rokan Hulu, dengan jumlah penduduk 23.774 jiwa,5.756 KK dan luas wilayah +$1,130,45 \mathrm{~km}^{2}$ yang membawahi 13 Desa 1 Kelurahan, serta Kecamatan Rokan IV Koto mempunyai Potensi Bisnis seperti, karet, sawit, pasir batu, dan wallet serta pasar dan alternatif jawaban, yang penulis uraikan sebagai berikut :

$\begin{array}{ll}\text { Kurang Baik } & \text { : Bobot Nilai 1 } \\ \text { Cukup Baik } & \text { : Bobot Nilai 2 } \\ \text { Baik } & \text { : Bobot Nilai 3 }\end{array}$

Jadi jumlah responden yang terdapat pada jawaban kuisioner dikalikan sesuai bobot nilai yang tertera diatas. Setelah itu jumlahkan untuk mendapatkan skor, baru dianalisis menurut ketentuan skalikert.

Waktu penelitian yang penulis pergunakan kurang lebih selama 6 bulan yang meliputi 45 hari untuk persiapa, 60 hari masa penelitian lapangan, 45 hari pengolahan data dan 30 hari penulisan laporan. juga koperasi, juga daerah yang sangat strategis sehigga sangat rawan untuk dicaplok oleh daerah lain.

Kecamatan Rokan IV Koto mempunyai Batas wilayah :

a. Sebelah utara berbatas dengan Kecamatan Rambah Kabupaten Rokan Hulu

b. Sebelah selatan berbatas dengan Kecamatan Pandalian IV Koto

c. Sebelah timur berbatasan dengan Kecamatan Kabun

d. Sebelah barat berbatas dengan Provinsi Sumatra Barat

\section{Hasil Penelitian \& Pembahasan}

2.Rekapitulasi Jawaban Responden dari Hasil Penelitian Tentang Evaluasi Tugas Camat dalam melakukan Pembinaan Penyelenggaraan Pemerintahan Desa di Kecamatan Rokan IV Koto Kabupaten Rokan Hulu. 
Tabel Rekapitulasi Tanggapan Responden Unsur Pembina dari Evaluasi Tugas Camat Dalam Membina Penyelenggaraan Pemerintahan Desa Di Kecamatan Rokan IV Koto Kabupaten Rokan Hulu

\begin{tabular}{|c|c|c|c|c|c|}
\hline \multirow{3}{*}{$\begin{array}{l}\mathbf{N} \\
\mathbf{0}\end{array}$} & \multirow{3}{*}{ Indikator } & \multicolumn{3}{|c|}{ Skala Likert } & \multirow{3}{*}{$\begin{array}{c}\text { Juml } \\
\text { ah/ } \\
\text { Total } \\
\text { Skor }\end{array}$} \\
\hline & & $\begin{array}{l}\text { Sk } \\
\text { or } \\
\text { Ba } \\
\text { ik }\end{array}$ & $\begin{array}{c}\text { Sko } \\
\text { r } \\
\text { Cuk } \\
\text { up } \\
\text { Bai } \\
\text { k }\end{array}$ & $\begin{array}{c}\text { Skor } \\
\text { Kura } \\
\text { ng } \\
\text { Baik }\end{array}$ & \\
\hline & & 3 & 2 & 1 & \\
\hline 1 & $\begin{array}{l}\text { Efektivita } \\
\mathrm{s}\end{array}$ & $\begin{array}{c}10 \\
8\end{array}$ & 54 & 21 & 183 \\
\hline 2 & Efisiensi & 87 & 97 & 35 & 219 \\
\hline 3 & $\begin{array}{l}\text { Responsiv } \\
\text { itas }\end{array}$ & 84 & 44 & 62 & 190 \\
\hline 4 & $\begin{array}{l}\text { Pemberia } \\
\mathrm{n} \\
\text { Bimbinga } \\
\mathrm{n}\end{array}$ & 96 & 70 & 50 & 216 \\
\hline 5 & Supervisi & 45 & 28 & 19 & 92 \\
\hline 6 & $\begin{array}{l}\text { Konsultas } \\
\mathrm{i} \\
\text { Pelaksana } \\
\text { an Urusan } \\
\text { Pemerinta } \\
\text { han }\end{array}$ & 15 & 20 & 36 & 71 \\
\hline & Total Skor & $\begin{array}{c}43 \\
5 \\
\end{array}$ & 313 & 223 & 971 \\
\hline
\end{tabular}

Sumber : Olahan data Penulis, 2018

$\mathrm{Y}=$ skor tertinggi liker $\mathrm{x}$ jumlah responden

$\mathrm{X}=$ skor terendah liker $\mathrm{x}$ jumlah responden

Total skor $=971$

Skor Tertinggi $4 \times 1$ Indikator $=84$

Skor Tertinggi $4 \times 6$ Indikator $=2.016$

Jadi,

Hasil : 971/2.016 x 100

$=48.16 \%$

$=48 \%$ Kategori Cukup Baik 
Tabel Rekapitulasi Tanggapan Responden Unsur Dibina dari Evaluasi Tugas Camat Dalam Membina Penyelenggaraan Pemerintahan Desa Di Kecamatan Rokan IV Koto Kabupaten Rokan Hulu

\begin{tabular}{|c|c|c|c|c|c|}
\hline \multirow{3}{*}{$\begin{array}{l}\mathbf{N} \\
\mathbf{0}\end{array}$} & \multirow{3}{*}{ Indikator } & \multicolumn{3}{|c|}{ Skala Likert } & \multirow{3}{*}{$\begin{array}{c}\text { Juml } \\
\text { ah/ } \\
\text { Total } \\
\text { Skor }\end{array}$} \\
\hline & & $\begin{array}{l}\text { Sk } \\
\text { or } \\
\text { Ba } \\
\text { ik }\end{array}$ & $\begin{array}{c}\text { Sko } \\
\text { r } \\
\text { Cuk } \\
\text { up } \\
\text { Bai } \\
\text { k }\end{array}$ & $\begin{array}{c}\text { Skor } \\
\text { Kura } \\
\text { ng } \\
\text { Baik }\end{array}$ & \\
\hline & & 3 & 2 & 1 & \\
\hline 1 & $\begin{array}{l}\text { Efektivita } \\
\mathrm{s}\end{array}$ & $\begin{array}{c}16 \\
2\end{array}$ & 444 & 96 & 702 \\
\hline 2 & Efisiensi & $\begin{array}{c}27 \\
3 \\
\end{array}$ & 424 & 213 & 910 \\
\hline 3 & $\begin{array}{l}\text { Responsiv } \\
\text { itas }\end{array}$ & $\begin{array}{c}21 \\
3\end{array}$ & 346 & 252 & 811 \\
\hline 4 & $\begin{array}{l}\text { Pemberia } \\
\mathrm{n} \\
\text { Bimbinga } \\
\mathrm{n}\end{array}$ & $\begin{array}{c}21 \\
6\end{array}$ & 328 & 260 & 804 \\
\hline 5 & Supervisi & 63 & 68 & 162 & 293 \\
\hline 6 & $\begin{array}{l}\text { Konsultas } \\
\text { i } \\
\text { Pelaksana } \\
\text { an Urusan } \\
\text { Pemerinta } \\
\text { han }\end{array}$ & 93 & 212 & 101 & 406 \\
\hline & Total Skor & $\begin{array}{l}1.0 \\
20\end{array}$ & $\begin{array}{c}1.82 \\
2\end{array}$ & 1.084 & 3.926 \\
\hline
\end{tabular}

Sumber : Olahan data Penulis, 2018

$\mathrm{Y}=$ skor tertinggi liker $\mathrm{x}$ jumlah responden

$\mathrm{X}=$ skor terendah liker $\mathrm{x}$ jumlah

responden

Total skor $=3.926$

Skor Tertinggi $4 \mathrm{x} 1$ Indikator $=372$

Skor Tertinggi $4 \times 6$ Indikator $=$ 8.928

Jadi,

Hasil : 3.926/8.928 x 100

$=43,97 \%$

$=44 \%$ Kategori Cukup Baik

Kesimpulan

Berdasarkan Penelitian lapangan yang penulis lakukan yang berkaitan dengan judul Evaluasi Pelaksanaan Tugas Camat dalam Membina Penyelenggaraan Pemerintahan Desa Di Kecamatan Rokan IV Koto Kabupaten Rokan Hulu. Maka dapat disimpulkan 
berdasarkan 2 tujuan penelitian yaitu :

1. Sesuai hasil rekapitulasi pengukuran analisis skalalikertyang ada berdasarkan 6 indikator yaitu Efektivitas, Efisiensi,Responsivitas, Pemberian Bimbingan, Supervisi, dan Konsultasi Pelaksanaan Urusan Pemerintahan, maka dapat disimpulkan Hasilnya berada pada kategori Cukup Baik dengaPersentase $44 \%$. Selanjutnya berdasarkan Hasil Wawancara kepada Camat yang diwakiliSekcam dan Kasi PMD maka yang bisa penulis simpulkan Pembinaan yang dilakukan terkesan sambilan, dan tidak direncanakan sesuai TUPOKSI. Selanjutnya penulis menganalisa baik berdasarkan kuisioner, wawancara dan observasi penulis menyimpulkan Pembinaan penyelenggaraan PemerintahanDesa Berada Pada Kategori Cukup Baik, meskipun hal tersebut didasari oleh beberapa hambatan.

2. Kesimpulan dari hambatan pelaksanaan tugas camat dalam pembinaan penyelenggaraan pemerintahan desa yaitu tidak adanya kejelasan pendelegasian kewenangan dari Bupati kepada camat mengenai uraian tugas dan penganggaran untuk pelaksanaan tugas yang berkaitan dengan pasal 154 Peraturan Pemerintah Nomor 43 Tahun 2014 tentang Peraturan Pelaksana dari undang-undang nomor 6 Tahun 2014 tentang Desa, selanjutnya yang menjadi hambatan juga dalam pelaksanaan pembinaan yaitu tidak adanya juklak juknis mengenai pembinaan serta skala pembinaan sehingga pembinaan yang dilakukan camat hanya berupa pengarahan dan terkesan sambilan serta tidak fokusnya pembinaan yang dilakukan.

\subsection{Saran}

Berdasarkan kesimpulan tersebut maka penulis dapat merumuskan saran sebagai berikut :

1. Seharusnya pemerintah daerah kabupaten Rokan Huludalam hal ini Bupati sebagai pelimpahan kewenangan dari Bupati kepada Camat menjelaskan dan memberikan penganggaran biaya mengenai pembinaan penyelenggaraan pemerintahan desa sehingga, sehingga pemerintahan bisa membuat program pembinaan.

2. Seharusnya dalam melaksanakan tugas penyelenggaraan pemerintahan yang berkaitan dengan pembinaan pemerintah kecamatan memberikan TUPOKSI yang jelas mengenai uraian tugas yang akandilaksanakan oleh pihak kecamatan sehingga jelas rencana pembinaan yang akan dilakukan.

3. Seharusnya pemerintahan desa berpartisipasi mendukung pembinaan yang diadakan oleh pihak kecamatan shingga pembinaan berjalan lancar sesuai antara yang diharapkan dengan yang terjadi dilapangan (balance of das sein and das solen).

4. Seharusnya pemerintahan Kecamatan Rokan IV Koto lebih bertangungjawab dalam melaksanakan pembinaan sehingga 
apapun yang dihasilkan baik dari musrenbangdes yang di syahkan pada musrenbang tingkat kecamatan sesuai dengan apa yang direncanakan, sehingga seharusnya fokus pembinaan harus jelas, terstruktur, terjadwal dan tidak terkesan sambilan.

5. Seharusnya pembinaan yang dilakukan tidak terkendala pada jarak desa dan pembinaan dilakukan merata pada seluruh desayang ada dengan dikumpulkan padal tempat dalam rangka pembinaan, sehingga tidak ada diskriminasi antara desa yang dekat dengan kecamatan dan desa yang posisinya jauh dengan kecamatan, terkait penyelenggaraan pemerintahan desa, baik mengenai pelaporan dari desa kepada kecamatan seharusnya agak lebih di perhatikan sehingga tidak terkesan saling menutupi.

6. Seharusnya pemerintahan kecamatan jika memang melaksanakan pembinaan hendaknya membuat arsip kegiatan pelaksanaan kegiatan baik berupa jadwal, waktu dan tempat sertatema kegiatan yang akan dilaksanakan sehingga mudah untuk dijadikan acuan dalam pembinaan berikutnya sehingga tau barometer pembinaan berikutnya supaya tau berhasil atau tidaknya serta tau mengidentifikasi kekuarangan yang telah lalu untuk kesempurnaan pembinaan berikutnya.

7. Hendaknya Pemerintah Kecamatan Rokan IV Koto juga membuat arsip kegiatan untuk memudahkan kegiatan-kegiatan pembinaan berikutnya supaya jelas rincian tanggal, hari, dan waktu melakukan pembinaan.

8. Seharusnya pihak yang dibina dalam pelaporan SPJ (Surat Pertanggung Jabawan) pelaporan bulanan, LPJ (Laporan Pertanggung Jawaban) kegiatan tahunan sesuai dengan SPT (Surat Perintah Tugas), dan seharusnya Kepala Desa menyelesaikan LPJ tersebut sebelum waktu yang ditentukan sehingga BPD juga masih bisa membaca LPJ tersebut dan tidak main tanda tangan aja oleh BPD sehingga tercipta koordinasi yang baik.

9. Seharusnya Pemerintahan Desa juga mampu melahirkan perdes dan perkades mengenai penyelenggaraan pemerintahandesa terkait pembinaan penyelenggaraan pemerintahandesa dari pihak kecamatan dalamhal ini khususnya perdes mengenai administrasi tata pemerintahandesa.

\section{Daftar Kepustakaan}

Abu ahmadi dan cholid Narbuko, 2009. Metodologi Penelitian, Jakarta, PT Bumi Aksara.

Achmad, 2010. Teori-Teori Mutakhir Administrasi Publik, Yogyakarta, Rangkang Education.

Ahmad Tanzeh, 2009. Pengantar Metode Penelitian, Yogyakarta, teras.

Ali, 2012. Kepemimpinan Transformasional Dalam Birokrasi Pemerintahan, 
Jakarta, Multicerdas

Publishing.

Apter,1965. Comporative Politics,

New York, The Free Press.

Ateng, Syafrudin, 2006. Mengarungi Dua Samudra, Sayagatama, Jakarta.

Brataha I. Nyoman, 1982, Masyarakat Desa dan Pembangunan Desa, Jakarta, Ghalia Indonesia

Diana, Halim Koentoero, 2004. Hukum Administrasi Negara, Bogor Selatan, Ghalia Indonesi.

Djaenuri, 2015. Kepemimpinan Etika dan Kebijakan Pemerintahan, Bogor, Ghalia Indonesia.

Effendy, 2009. Pergeseran kepemimpinan desa kharismatik paternalistik, otokratik, demokratik, Bandung, Indra Prahasta.

Hasibuan, Malayu, S. P, 2001, Manajemen Sumber Daya Manusia, Jakarta, PT. Bumi Aksara.

Ismail, Maimunah. 2001. Pengembangan Implikasi Keatas Pembangunan Masyarakat. Dewan Nawawi, hadari,2005, Metode Penelitian Sosial. Gajah Mada. Yogyakarta

Iver, R. Mac, 1947. The Web of Government, Tha Mac Millan Company Ltd. New

Kartono, 2014. Pemimpin dan kepemimpinan, Jakarta, Raja Grafindo Persada.

Karyadi (Thoha , Miftah,1999) (dalam jurnal Rendra).
Pembinaan Organisasi, Jawa Press, Jakarta

Kusnadi,2005. Pengantar Manajemen. Unibraw Press, Malang

Miftah, Thoha, 2010. Pembinaan Organisasi Proses Diagnosa dan Intervensi, Jakarta, PT RajaGrafindo Persada

Miriam Budiardjo, 1998. Dasardasar Ilmu Politik, Jakarta , Gramedia Pustaka Utama.

Musanef, $1998 . \quad$ System Pemerintahan di Indonesia. Gunung Agung, Jakarta

Nanang Martono, 2011. Metode Penelitian Kuantitatif, Rajawali Pers, Jakarta.

Nawawi, hadari, 2005. Metode Penelitian Sosial, Gajah Mada, Yogyakarta

Ndraha, 2003. Kybernology Ilmu Pemerintahan Baru, Jakarta, Rineka Cipta.

Nurcholis, Hanif, 2005, Pemerintahan dan Otonomi Daerah, Jakarta, Alfabet

Pamudji, 1986. Kepemimpinan Pemerintahan di Indonesia, Jakarta, Bina Aksara.

Philipus M. Hadjon, Tentang Wewenang, Makalah, Universitas Airlangga, Surabaya, tanpa tahun.

Ratminto, 2005. Manajemen Pelayanan Publik, Yogyakarta, Pustaka Belajar.

Rauf Rahyunir, 2016. Posisi Dewan Perwakilan Rakyat Daerah dalam Sistem Pemerintahan Daerah, Marpoyan Tujuh Publishing, Pekanbaru. 
Rewansyah, 2012. Kepemimpinan dalam pelayanan publik, Jakarta, Rizki Grafis.

Ridwan HR, 2006. Hukum Administrasi Negara, PT. Raja Grafindo Persada, Jakarta.

Rosenthal, 1978. Openbaar Bestuur, Samson HD, Jeen Willink, Alphen aan den Rijn, Leiden.

Santoso, 2010, Pembinaan Dalam Organisasi. Jakarta, Gramedia Pustaka

Sedarmayanti, 2009. Repormasi Administrasi Publik, Reformasi Birokrasi \& Kepemimpinan Masa depan (Mewujudkan Pelayanan Prima dan kepemerintahan yang baik), Bandung, Refika Aditama.

Sinambela, dkk. 2011. Reformasi Pelayanan Publik Teori, Kebijakan, dan Implementasi, Jakarta, Bumi Aksara.

Soehino, 2002. Perkembangan Pemerintahan di Daerah, Yogyakarta, Liberty.

Syafiie, 2011. Sistem Pemerintahan Indonesia, Jakarta, Rineka Cipta.

Suradinata, 2014. Alanisis Kepemimpinan Strategi Pengambilan Keputusan, Bandung, Alqaprint Jatinangor.

Tisnawati Sule, Erni danKurniawan Saefuulah, 2005. Pengantar Manajemen, Jakarta, Kencana.
Thoha, Miftah, 2008. Ilmu Administrasi Publik Kontemporer.

Wasistiono, 2014. Jurnal Ilmu Pemerintahan, Jakarta, Masyarakat Ilmu Pemerintahan Indonesia

William A. Cohen, 1992. Seni Kepemimpinan. Jakarta, Mitra Utama.

di Keamatan, M. P. N. S., \& Hulu, S. Evaluasi Pelaksanaan Peraturan Pemerintah Nomor 45 Tahun 2007 Tentang Persyaratan dan Tata Cara Pengangkatan Sekretaris Desa.

Ispik, A., Yogia, M. A., Wedayanti, M. D., \& Zainal, Z. (2021). The Influence of Discipline on Performance of Employees Office of the Ministry of Religion. Pekanbaru City.

Subhayano, T., Yogia, M. A., Wedayanti, A. A. P. M. D., \& Zainal, M. L. H. (2021). Good Governance in Maintaining Peace and Order at Pangkalan Kerinci District. Pelalawan Regency.

Ispik, A., Yogia, M. A., Purwati, A. A., Wedayanti, M. D., \& Zainal, M. L. H. (2021). Analysis of Benefits, Discipline and Leadership Style in improving Employee Performance of the Ministry of Religion in Pekanbaru, Indonesia.

Nasri, H., Nurman, N., Azwirman, A., Zainal, Z., \& Riauan, I. (2022). Implementation of collaboration planning and budget performance information for special allocation fund in budget planning in the regional 
development planning agency of Rokan Hilir regency. International Journal of Health Sciences (IJHS) Ecuador, 6(S4), 639651.

Munir, A., Wahyudi, S., \& Zainal, Z. (2020). Tinjauan Kriminologi Terhadap Sensual Marketing Sebagai Strategi Pemasaran Produk Yang Diperankan Oleh Sales Promotion Girl Di Kota Pekanbaru. Wedana: Jurnal Kajian Pemerintahan, Politik dan Birokrasi, 6(2), 21-35.

Subhayano, T., Yogia, M. A., Wedayanti, M. D., \& Zainal, Z. (2021). The Role of the Camat in Coordinating the Administration of Peace and Order in Pangkalan Kerinci District Pelalawan Regency.

Suwaryo, H. U., \& Redjo, H. S. I. (2018). Transformasi Hubungan Pemerintah Pusat Dan Pemerintah Daerah Dalam Pemberian Izin Hutan Tanaman Industri Bagi Swasta Di Provinsi Riau Tahun 20102015.

Wicaksono, A. (2022, April). Peatlands Restoration Policies in Indonesia: Success or Failure?. In IOP Conference Series: Earth and Environmental Science (Vol. 995, No. 1, p. 012068). IOP Publishing.

Yogia, A. S. M. A., Rahman, Z. M. D. W. K., \& Purwati, A. A. (2021). Leadership of Tourism and Culture Department in Development of Cultural Reserves at District Kuantan
Singingi.

Zainal, Z., \& Nurdasanah Putri, F. (2021). Government Management in Village-Owned Enterprises in Increasing Village Original Income In Kampar District.

Halim, N. A., Rosidi, I., Haris, A., Yesicha, C., \& Riauan, M. A. I. Media dan Politik.

Riauan, M. A. I., Aziz, A., \& Nurman, N. (2020). Analisis Framing" Aksi Bela Islam" sebagai Dakwah Islam di Riau Pos (A Framing Analysis of" Islam Defense Action" as Islamic Dakwah on Riau Pos Newspaper). Jurnal Dakwah Risalah, 31(1), 35-47.

Riauan, M. A. I., Qurniawati, E. F., Aslinda, C., \& Aziz, A. (2020). Konstruksi Realitas Pada Pesan Politik Calon Walikota Pekanbaru di Riau Pos. ETTISAL: Journal of Communication, 5(1).

Riauan, M. A. I., Kholil, S., \& Sikumbang, A. T. (2019). Islamic Symbols on Political Messages in Newspapers in Riau (Study in Regional Head Election 2017). Budapest International Research and Critics Institute-Journal (BIRCI-Journal), 2(1), 254-262.

Riauan, M. A., Sari, G. G., Aslinda, C., \& Qurniawati, E. F. (2018). Konstruksi Makna Ketergantungan dalam Perilaku Merokok. Relasi Negara Industri Dan Masyarakat Dalam Perspektif Komunikasi, 171.

Riauan, M. A. I., \& Shasrini, T. 
(2017). Dampak Komunikasi Terapeutik terhadap Citra Pelayanan Kesehatan (Studi Kasus di Rumah Sakit Umum Daerah Arifin Achmad Pekanbaru). Jurnal The Messenger, 9(1), 31-43.

Riauan, M. A. I. (2016). Figur Politik Calon Walikota Pekanbaru Septina Primawati Rusli dan Erizal Muluk Pada Pemilukada Kota Pekanbaru 2011. Medium, 4(2).

Riauan, M. A. I. (2013). Penggunaan Teknologi Komunikasi dalam Penerapan Good Governance. Jurnal Kajian Pemerintahan, 2(2), 102-107.

Riauan, M. A. I. (2012). Studi Komparatif Aktivitas Humas Antara Pemerintah Provinsi Riau dengan PT. Chevron Pacific Iindonesia. Medium, 1(1).

Sari, G. G., Wirman, W., \& Riauan, M. A. (2018). Pergeseran Makna Tradisi Bakar Tongkang Bagi Generasi Muda Tionghua di Kabupaten Rokan Hilir Provinsi Riau. 